\title{
A COMPARISON BETWEEN THE COMMENTS ON DANIEL IN THE SYRIAC COMMENTARY ON THE DIATESSARON AND THE SYRIAC COMMENTARY ON DANIEL
}

\author{
Phil J. Botha \\ (University of Pretoria)
}

\begin{abstract}
This short article investigates the possibility of connections between the Syriac Commentary on Daniel, ascribed to Ephrem, and the Syriac Commentary on the Diatessaron, also thought to consist of exegetical notes made by Ephrem with some additions and interpolations added to it. Two themes from the book of Daniel that receive special attention in the Commentary on the Diatessaron are scrutinised, namely the stone that became dislodged from a mountain in Daniel 2 and the prophecy about the destruction of Jerusalem in Daniel 9. It seems that the two commentaries follow a similar trajectory of interpretation, suggesting proximity in time and place of origin.
\end{abstract}

\section{Introduction}

Ephrem the Syrian is said to have written commentaries on all the books of the Bible, ${ }^{1}$ but only the commentaries on Genesis and Exodus from the Old Testament $^{2}$ and the commentary on the Diatessaron from the New Testament seem to be unquestionably his work. ${ }^{3}$ This short article investigates the general character of the Commentary on Daniel attributed to him, ${ }^{4}$ and possible links it may have with the Commentary on the Diatessaron which definitely has some connections with the work of Ephrem, although it cannot be described as being homogeneous or completely authentic his work.

What are the arguments for or against Ephrem's having written the commentary on Daniel? In favour of his authorship is the fact that it is extant in Syriac. ${ }^{5}$ It is based on the Peshitta text of Daniel, ${ }^{6}$ and it contains interpretations similar to those found in Ephrem's genuine hymns. ${ }^{7}$ There is a typical high regard for the literal sense of the text, ${ }^{8}$ but also occasional symbolic interpretation. ${ }^{9}$ The author displays an openness towards multiple possible interpretations of a specific verse. ${ }^{10}$ The commentary also does not seem to contain references to theological developments which occurred after the time of Ephrem, ${ }^{11}$ or views that seem to clash with his theology. But one has to acknowledge that Ephrem's poetic genius and his consistent identification of polarities and symbols which connect heaven and earth 
and the two Testaments antithetically seem to be lacking from the commentary. ${ }^{12}$ It also lacks clear signs of Ephrem's controversy against the followers of Bardaisan, Mani, Marcion, and Arius, although it does polemicise against the Jews. ${ }^{13}$

The Syriac Commentary on the Diatessaron alludes to the text of Daniel a number of times. ${ }^{14}$ In this paper, the symbolism of the rock in Nebuchadnezzar's dream in Dan 2 and the 'prophecy' about the crucifixion of Christ and the destruction of Jerusalem in the Peshitta text of Dan 9 will be investigated as examples of the similarities and differences between the two commentaries.

\section{The interpretation of the rock in Dan 2}

Nebuchadnezzar's dream about a statue and Daniel's explanation of the dream are seen by the author of the Commentary on Daniel to contain a number of symbols. The kingdom which God will set up according to Dan 2:44 refers to the Maccabees, the author tells us, but their kingdom serves as a symbolical depiction of 'the Lord who is the true fulfilment'. This is so because the text speaks of a 'rock that was cut out without hands' (Dan $2: 45$ ). This, he says, 'is the Lord who was born in humbleness like a stone from the mountain, namely, from the lineage of the house of Abraham'. He goes on to interpret the mountain also symbolically: it signifies 'the Holy Virgin', since the rock was cut out from her 'without hands', implying that there 'was no sexual union from her'. But the rock is finally also interpreted as the Gospel, since the statement that 'the whole earth was filled from it' (Dan 2:35), refers to 'the Gospel that quickly spread everywhere'.

The true meaning of the vision is thus that it refers to the birth of Christ from the Virgin Mary, the dissipation of the Gospel, ${ }^{15}$ and the eschatological advent of Christ's kingdom. The interpretation of Christ as the rock in Dan 2 was widespread in primitive and early Christianity ${ }^{16}$ and even more so in the Syriac fathers, since the word kepha is more common in the Peshitta than any one word for rock or stone in the Hebrew or Greek versions of the Old and New Testaments respectively. ${ }^{17}$ Both Aphrahat and Ephrem associated a host of 'rock testimonies' with Christ, but the commentary here has a reference to an Old Testament testimony text which is nowhere mentioned by Murray in his extensive treatment of Christ as the rock in early Syriac tradition. It is also not found in Aphrahat's Demonstrations. It lies hidden in the remark that the mountain refers to 'the lineage of the house of Abraham', and that the 'Holy Virgin' is conse- 
quently called 'the mountain, since he was cut out from her'. The reference to the 'lineage of Abraham' seems puzzling, until one realises that this is an implicit allusion to Isa 51:1-2. The key is provided by the Commentary on the Diatessaron, Chapter II§3. The author is trying to prove there that the Virgin's conception was without intercourse, and calls Isa 7:14 ('behold the virgin will conceive') and Dan 2:34 and 45 as witnesses: 'A stone was cut off, but not with [human] hands'. He then goes on to remark: ${ }^{18}$

This is not like that [other passage], Look at the mountain and the cistern (Isa 51:1); since that [passage implies] a man and a woman, whereas here it is [written], Not with [human] hands. Just as Adam fills the role of father and mother for Eve, so too does Mary for our Lord.

Isaiah 51:1-2 says:

${ }^{1}$ Listen to me, you who pursue justice, who seek Yahweh; look to the rock from which you were hewn, to the pit from which you were quarried; ${ }^{2}$ look to Abraham, your father, and to Sarah, who gave you birth; when he was but one I called him, I blessed him and made him many.

The Peshitta does not speak of a rock in verse 1, but of a mountain. The second part of this verse reads: ${ }^{19}$

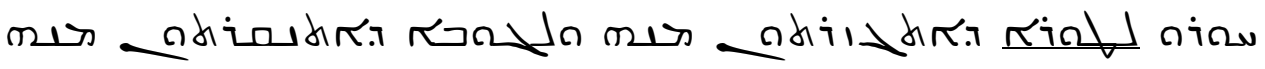

'Look to the mountain from which you were hewn, and to the pit from which you were quarried.'

The argument thus runs as follows: Daniel speaks of a rock that was hewn out (iLis ) from a mountain ( ( which Christ was 'hewn' must then be Mary, especially since this was done without human hands, that is, without sexual activity. In Isa 51:1-2 the mountain ( $\kappa_{i} \downarrow$, translated thus only in the Peshitta) from which Israel was

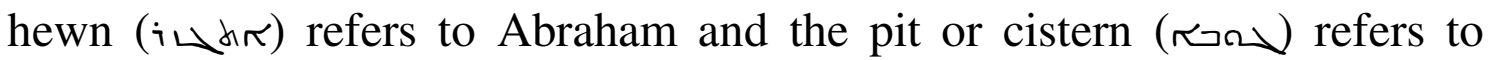
Sarah, but according to Daniel, Mary is also called a mountain, so that she represents both Abraham and Sarah, thus the lineage of Abraham. The remark in the Commentary on Daniel about 'the lineage of the house of 
Abraham' makes sense only if the context of Isa 51:1-2 in the Peshitta is taken into consideration as an allusion.

This similarity does not prove dependence of one commentary on the other, but it does suggest the existence of a mutual tradition, and notably one not found in Aphrahat. ${ }^{20}$ It is very interesting that Theodoret of Cyrus still knows this tradition, and refers to the same text in Isaiah, but uses it

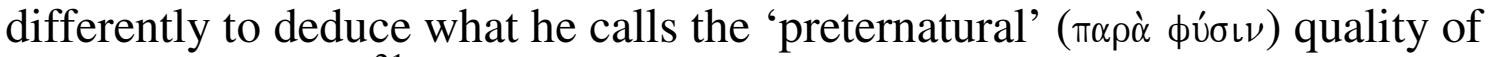
the birth of Christ. ${ }^{21}$ It thus seems that the Commentary on Daniel and the Commentary on the Diatessaron share an indigenous Syriac tradition of interpretation. This interpretation can also be described as 'symbolical', since the mountain is interpreted as signifying that Mary represented both father and mother for Christ, a fact that corresponds to Adam's position as both father and mother for Eve. Such a gender-matched chiastic comparison of Adam and Eve with Mary and Christ to argue for the virgin birth of Jesus does not only fit the theology of Ephrem, but would also have been typical of his masterful ability to see such typological correspondences. Theodoret's interpretation, in contrast, seems to be removed from this symbolical interpretation and seems to represent Christological thinking from a later era than that of the Commentary on the Diatessaron, and also from the time of Ephrem.

If a direct relationship between the two Syriac commentaries could be supposed, the Commentary on the Diatessaron would rather seem to be earlier since it is more explicit and provides the key for understanding the remarks in the Commentary on Daniel in this case. In comparison to the typical 'Ephremic' typology displayed by the Commentary on the Diatessaron, the interpretation in die Commentary on Daniel also seems rather bland, perhaps displaying greater distance from the genuine Ephrem.

\section{The destruction of Jerusalem prophesied in Dan 9}

It seems that the text of the Peshitta of Dan 9 already pointed readers in the direction of interpreting the 'prophecies' about the time of Antiochus IV Epiphanes as prophecies about the advent of Christ, his crucifixion, and the destruction of Jerusalem in 70 A.D. ${ }^{22}$

It is the prediction of the destruction of Jerusalem that interests the author of the Commentary on the Diatessaron most in this chapter. In Chapter XVIII 1 , he is commenting on Jesus' entry into Jerusalem and avails himself of the opportunity to point out that the 'Daughter of Zion' herself 
was the cause of Jerusalem's destruction: ${ }^{23}$

'But now that she has stretched forth her hands against the Son and crucified the Son of the living [God], her house has been uprooted and her altar overturned, just as the prophet had said, The holy city shall be destroyed, ${ }^{24}$ together with the king who is to come. And she will lie there in ruins until the completion of judgements. There will be no further pact or decree for her return, as [there was] from Egypt, or from Babylon, or from the Greeks, where a fixed term [in each case] was written down. For her then the judgement is decreed: there will be no fixed term for her, and no return.

In the Commentary on Daniel, the following comments are made on the prediction of the destruction of Jerusalem in Dan 9:

So after sixty-two weeks the Messiah will be killed. Namely, when the times that were given to you (plural) are completed, the Messiah will be killed. And there is no other Messiah for her. ${ }^{25}$ And the holy city will be laid waste ${ }^{26}$ with $^{27}$ the king who is coming. Namely, with the king, the Messiah who is coming and being crucified. And the rest in the flood. Namely, because those that remain from the death of the famine will go out in the flood of the captivity. Until the end of the judgements of the desolation it will persist for her on destruction. Namely, because this departure will not be like that from Egypt or Babylon. For from the first they were allowed to return after four hundred (years), and from Babylon after seventy. But this desolation of the judgement will remain for ever for her over the destruction.

The text of the Peshitta of Daniel prompted the idea that Jerusalem will be destructed 'with', that is, as a consequence of or at the time of, the killing of the Messiah. That the Messiah will be 'killed' (\๐ etpa) ${ }^{28}$ is itself an interpolation of the Peshitta, since the MT simply speaks of the 'cutting off' (כרת ni) of an anointed one. The Commentary on Daniel interprets this specifically as death by crucifixion, a connection which the author of the Commentary on the Diatessaron obviously has also made.

A second matter of correspondence is the description of the duration of the ruin of Jerusalem, as the text of Daniel is interpreted to prophesy. According to the Commentary on the Diatessaron, Jerusalem 'will lie there 
in ruins until the completion of judgements. There will be no further pact or decree for her return, as [there was] from Egypt, or from Babylon, or from the Greeks, where a fixed term [in each case] was written down. For her then the judgement is decreed: there will be no fixed term for her, and no return.' The Commentary on Daniel remarks in this regard: 'Until the end of the judgements of the desolation it will persist for her on destruction. Namely, because this departure will not be like that from Egypt or Babylon. For from the first they were allowed to return after four hundred (years), and from Babylon after seventy. But this desolation of the judgement will remain for ever for her over the destruction'.

The mentioning of the captivity in Egypt and in Babylon and the 'return' from both 'captivities' in the two sources seems to be important. These periods of captivity are not suggested by the MT or the text of the Peshitta of Dan 9, so that the references to them must be taken to signify a common tradition of interpretation of this chapter in Daniel. ${ }^{29}$ The two commentaries also seem to share the conviction that Jerusalem will remain in ruins for ever.

The Commentary on the Diatessaron refers to the permanent ruin of Jerusalem again later, showing how important this event was for the author's repeated argument that the Church has replaced the Israelites as the people of God (XVIII§12): ${ }^{30}$

[Jerusalem] was destroyed many times and then rebuilt, but here it is a question of its [total] upheaval and destruction and the profanation of its sanctuary, after which it will remain in ruins and fall into oblivion. ${ }^{31}$ The Romans placed standards representing an eagle within this temple just as [the prophet] had said, On the wings of impurity and ruination, the sign of its terrible destruction, foretold by the prophet Daniel. Some say that the sign of its destruction was the pig's head which the Romans gave Pilate to carry into the interior of the temple to place there.

The following remarks made in the Syriac Commentary on Daniel are noteworthy in this regard:

And on the wings of defilement, the devastation. Namely, because of the eagle which the Romans went in and placed in the temple with the statue of their king. This is namely that: When you see 
the defiled sign of which is spoken in the prophet Daniel, and until the completion of the judgements it will rest on the destruction. Namely, until the completion of the judgements it will be forgotten and rest on the destruction.

There seems to be two possible similarities here: First, the interpretation of 'wings' in the text of Daniel as referring to the standard of the Romans depicting an eagle, and second, the Diatessaron Commentary's remark that the sanctuary will 'fall into oblivion' and the Syriac Commentary on Daniel's remark that 'it will be forgotten'. Again, there is no element in the text that could have suggested this remark, so that it seems that the two commentaries also share a tradition of interpretation in this regard. Both seem to have originated in circumstances which dictated a polemical inclination towards the Jews and their endeavours to revive their political aspirations.

\section{Conclusion}

The Syriac Commentary on Daniel and the notes on Daniel in the Commentary on the Diatessaron seem to follow the same trajectory of interpretation. There are similarities between the two which seem to point towards proximity in time and area of origin. When the mountain mentioned in Dan 2 is interpreted in both sources as a reference to the Virgin Mary on the basis of Isa 51:1-2, they seem to share a tradition of interpretation which originated in the Syriac-speaking Church, since the impetus for this exegesis could only have been provided by the Peshitta version of Isaiah. Peculiarities of this Syriac trajectory of interpretation also distinguish it from the Greek tradition and even from the interpretation found in Ephrem's older contemporary, Aphrahat. Aphrahat gives no evidence that he knew this tradition of interpretation, and although lack of evidence does not prove that he did not know it, it makes the similarity between the two commentaries all the more conspicuous.

The authors of the two commentaries also seem to have shared a need to renounce the hope of the Jews ever to rebuild Jerusalem again or to revive the Davidic kingship. Both refer to the two earlier periods of captivity, namely in Egypt and Babylon, in this regard. This is an aspect of the interpretation which also lacks in the work of Aphrahat, and could possibly be used to argue for proximity of origin (in terms of a circle of influence) of the two Syriac commentaries. 
But even in the treatment of these two contexts from Daniel in which the two commentaries seem to display similarities or possible connections, one can also sense a difference. The Commentary on Daniel uses symbolic interpretation and it does have a sustained polemic against the Jews, similar to that found in the Commentary on the Diatessaron, but it seems to lack the brilliance found in the latter which would be one of the most convincing arguments for a close connection between certain material in the Commentary on the Diatessaron and Ephrem himself.

\section{NOTES}

$1 \quad$ Cf. Alfred Friedl, 'Ephräm der Syrer, $† 373$,' in W. Klein (ed.), Syrische Kirchenväter (Stuttgart, 2004), pp.36-56, p.40; and also Edward G. Mathews, 'General Introduction' in Kathleen McVey (ed.), St Ephrem the Syrian, Selected Prose Works. Commentary on Genesis, Commentary on Exodus, Homily on Our Lord, Letter to Publius. Translated by Edward G. Mathews and Joseph P. Amar (Washington, 1994), pp.3-56, p. 42.

2 Cf. Sebastian P. Brock, 'Ephrem and the Syriac Tradition,' in Frances Young, Lewis Ayres, and Andrew Louth (eds), The Cambridge History of Early Christian Literature, (Cambridge, 2004), pp.362-372, p.365 and Sidney H. Griffith, 'Ephraem the Exegete (306-373). Biblical Commentary in the Works of Ephraem the Syrian', in Charles Kannengiesser (ed.), Handbook of Patristic Exegesis. The Bible in Ancient Christianity, Vol. II (Leiden: 2004), pp.1395-1428, p.1403.

3 Although the Diatessaron Commentary is not entirely without problems. Cf. Sebastian Brock, A Brief Outline of Syriac Literature, (Kottayam, 1997), p.23. As McCarthy notes, it does not mean that everything in the commentary in its present form is from Ephrem, but that it would be 'unduly sceptical to remove Ephrem's name totally' from the work. Edmund Beck, for one, was hesitant to speak of 'Ephrem's commentary' in this regard and suggested that the name should be 'The Syriac Commentary on the Diatessaron'. Cf. Carmel McCarthy, Saint Ephrem's Commentary on Tatian's Diatessaron, an English Translation of Chester Beatty Syriac MS 709 with Introduction and Notes (Journal of Semitic Studies Supplement 2); (University of Manchester, 1993), pp.31-34. Louis Leloir, in contrast, referred to it as 'la plus importante des œuvres exégétiques d'Ephrem' (L. Leloir, Doctrines et Méthodes de S. Éphrem d'après son Commentaire de l'Évangile Concordant (original Syriaque et Version Arménienne), Corpus Scriptorum Chrisitanorum Orientalium (= CSCO), Vol. 220, (Louvain, 1961), p.40). Christian Lange (The Portrayal of Christ in the Syriac Commentary on the Diatessaron, Louvain: Peeters (CSCO 616), 2005, p.66) came to the conclusion that the commentary either goes back to lecture notes taken by Ephrem's disciples, or represents an independent 
compilation of 'authentic' and 'non-authentic' Ephrem material by a single later compiler. In contradistinction to Beck's position, Lange emphasises the fact that the 'compiler' of the commentary 'made use of a lot of authentic Ephraemic ideas and material' (Lange, op. cit., p.167).

Text and Latin translation in J. S. Assemani (ed.), Severus Catena: Sancti Patris nostri Ephraem Syri opera omnia quae exstant Graece, Syriace, Latine, in sex tomos distribute. Patris Nostri Ephraem Syri in Danielem Prophetam Explanatio, Vol. V; (Rome, 1740), pp. 203-233. I am aware of the fact that the manuscript on which this version of the text was based, seems to be suspect, but it was the only version available to me. Murray notes that Ephrem's 'authentic works are all in Syriac or preserved in Armenian versions'. Cf. Robert Murray, Symbols of Church and Kingdom: A study in early Syriac tradition (Cambridge, 1975), p.367.

Cf. Phil J. Botha, 'The Interpretation of Daniel 3 in the Syriac Commentary ascribed to Ephrem the Syrian', Acta Patristica et Byzantina 16 (2005), pp.29-53.

7 Cf. Botha, 'Daniel 3', and the forthcoming article by the same author, 'The Relevance of the Book of Daniel for Fourth-Century Christianity According to the Commentary Ascribed to Ephrem the Syrian' to be published in BZAW with the title: Die Geschichte der Daniel-Auslegung in Judentum, Christentum und Islam. Studien zur Kommentierung des Danielbuches in Literatur und Kunst.

8 Ephrem explicitly recognized two senses of the scriptural text, namely a literal and a spiritual sense. This is stated perhaps most clearly in his Commentary on Genesis at Gen 49. Cf. Griffith, 'Ephraem the Exegete', p. 1404.

9 The book of Daniel is interpreted in the commentary generally in a literal sense, with lessons being extracted from the example set by Daniel, such as his insistence to consecrate himself for the fast. But the author also recognises symbols in the text that refer to greater truths. The 'kingdom' which God will establish according to Dan 2:44, for instance, is explained as being delineated symbolically $(\widetilde{\kappa})$ ( $)$ in the "house of the Maccabees who subdued the kingdom of the Greeks, but in truth ( $\downarrow<\kappa_{i}$ ir) on the Lord who is following (after that)'. Ephrem insisted that Scripture has as many facets as there are exegetes and that its meaning can never be exhausted. Cf. Griffith, 'Ephraem the Exegete', p.1406, who quotes the beautiful passage from the Commentary on the Diatessaron from McCarthy's translation, Saint Ephrem's Commentary on Tatian's Diatessaron, pp.49-50.

12 With regard to the commentary on the Diatessaron, Carmel McCarthy cites Ephrem's use of symbolism and typology as distinctive characteristics which help to establish a link between the commentary and his person. His 
poetic genius, which constantly sought and found correspondence, balance, and contrast between personalities, institutions, and situations (especially between the two testaments), is also evident in the prose of the commentary on the Diatessaron. Cf. Carmel McCarthy, 'Allusions and Illusions: St Ephrem's Verbal Magic in the Diatessaron Commentary', in: Thomas Finan \& Vincent Twomey (eds), Scriptural Interpretation in the Fathers: Letter and Spirit (Cambridge, 1995), pp.143-162, p.145-148.

Mathews remarks with regard to the authenticity of Ephrem's commentary on Genesis that it sustains the polemics against the heresies of Marcion, Bardaisan, and Mani, a prominent feature of Ephrem's genuine hymns. Such a sustained polemic would be unlikely in a collection of later notes, he remarks. Cf. Edward Mathews, 'Introduction to the Commentary on Genesis', in McVey (ed.), St. Ephrem, Selected Prose Works, p.64.

According to the Index of Biblical References in McCarthy's translation of the Commentary on the Diatessaron, the following texts from Daniel are referred to in the commentary: Dan $1: 1-2 ; 2: 34$ and $35 ; 2: 45 ; 3: 21-97 ; 3: 49-$ $50 ; 4: 14 ; 6: 18 ; 8: 11-12 ; 9: 2 ; 9: 24-27 ; 9: 26-27,9: 27$ on its own; and 11:3139. Cf. McCarthy, Saint Ephrem's Commentary on Tatian's Diatessaron, p.357. To these, Louis Leloir adds Dan 4:22 and 29 as well as 12:11. Cf. Éphrem de Nisibe, Commentaire de l'Évangile Concordant ou Diatessaron. Traduit du Syriaque et de l'Arménien, Introduction, Traduction et Notes par Louis Leloir (Paris, 1966), p.414. The importance of Dan 2 and 9 is evident from these lists.

This interpretation was also known and referred to by Ephrem. In the teaching songs De Resurrectione 3:17 (CSCO Vol. 248, Syr. 108, ed. by Edmund Beck, 1964, p.88) he writes that the stone which Daniel saw and the cloud which Elijah saw from Carmel both grew to fill the whole world and the whole sky respectively, so that they form types of the Gospel that 'filled the whole world'.

It is already found in Luke 20:18, where Dan 2:35 and 44 are alluded to (cf. Murray, Symbols, p.205). Isa 5:28 (with a reference to the 'solid rock' in the LXX) contributed to this (cf. Murray, Symbols, pp.208, 210). It is continued in the second century (alluded to in Justin's Dialogue with Trypho 70:1, 76:1, 100:4, and 114:4) and in the commentary of Hippolytus of Rome at the beginning of the third century (see J. J. Collins, Daniel, Hermeneia (Minneapolis, 1993), p.112). Justin already interprets the description of a rock cut out without hands as signifying that Christ 'was not the product of human activity, but of the will of God' (Chapter 76:1, translation quoted from Saint Justin Martyr, Dialogue with Trypho by Thomas B. Falls, 1948, The Fathers of the Church, A New Translation, vol. 6, p.268). Hippolytus mentions it in his commentary at Chapter II§13. Translation consulted in Hippolyte, Commentaire sur Daniel, texte établi et 
traduit par Maurice Levèvre, 1947 (Sources Chrétiennes 14), pp.106-107. Ephrem also displays knowledge of this in his teaching songs $D e$ Virginitate 14:6 (CSCO Vol. 223, Syr. 94, ed. by E. Beck, 1962, p.49). 
Pennsylvania. Leipzig, 1923). Kallarakkal's investigation (A. G. Kallarakkal, 'The Peshitto Version of Daniel - A Comparison with the Massoretic Text, the Septuagint and Theodotion'. Dissertation zur Erlangung der Doktorwürde der Evangelisch-Theologischen Fakultät der Universität Hamburg, 1973) led to the conclusion, contrary to that of Wyngarden, that the translator of the Peshitta was a Jew. Taylor (pp.15-16) has argued convincingly that Kallarakkal's arguments do not provide any proof of this. Cf. also M. Henze, The Madness of King Nebuchadnezzar. The Ancient Near Eastern Origins and Early History of Interpretation of Daniel 4, Supplements to the Journal for the Study of Judaism, 61; Leiden, 1999, pp.144-146 for a discussion of the three studies on the Peshitta of Daniel. Henze (p.146) thinks that any argument about a Jewish or Christian provenance based on exegetical observations exclusively is 'circular at best and bound to fail.'

Quoted from the translation of McCarthy, Saint Ephrem's Commentary on Tatian's Diatessaron, p.270.

McCarthy inserts a note here which refers to Dan 8:11-12, 9:26-27, and 11:31-39.

The Hebrew words in Dan 9:26, 'יאין לו' 'he will have nothing,' is rendered by the Peshitta as a third person feminine suffix attached to the preposition, thus 'and she will have none/nothing.' This could then easily be taken to refer to the city or the people, who, as the commentary notes, "will have no other Messiah.' In his teaching songs De Virginitate 28:8 Ephrem alludes to this text with the words 'the king is being killed and there will be no other king.' Cf. CSCO Vol. 223, Syr. 94, ed. by E. Beck, 1962, p.103. The context of the argument requires that he uses דـ דلح there, while the Peshitta earlier (v. 25) also refers to ת ת ת.r.

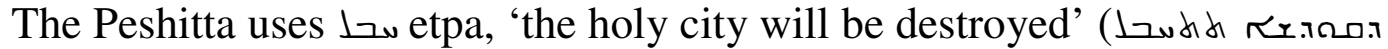

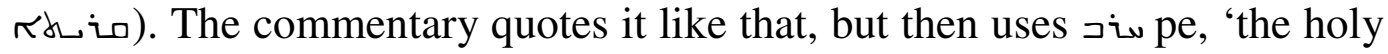

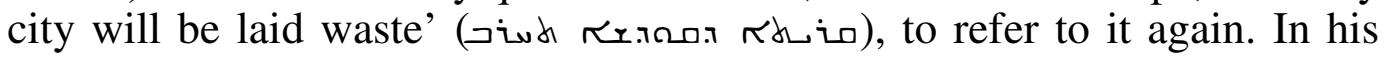
teaching songs De Nativitate 25:7, Ephrem uses the same verb in the same

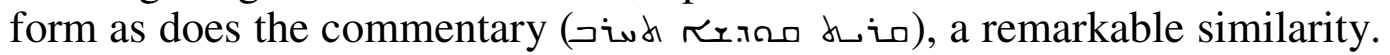
Cf. CSCO Vol. 186, Syr. 82, ed. by E. Beck, 1959, p.129. The MT's עם, 'people' has become 'with' in the Peshitta. Peshitta Institute, The Old Testament in Syriac, according to the Peshitta Version. Part III, Fascicle 4, Dodekapropheton - Daniel-Bel-Draco. Leiden: E. J. Brill, 1980, p. 36 (v. 26).

In this instance, the comments in the Commentary on the Diatessaron seem like a development of the comments in the Commentary on Daniel, since it adds the 'captivity' under the Greeks to those in Egypt and Babylon. This does not have to be the case, of course, since the author is now looking back to the time of the Seleucids, while the commentary on Daniel is interpreting the prophecy about the Seleucids as referring to the Romans and thus conveniently skips that crisis. Aphrahat similarly deduces from 
Dan 9 and repeatedly insists that Jerusalem will not be rebuilt, but does not make a similar comparison to Egypt, Babylon, or the Greeks in this regard. Cf. Demonstration XVII§10, XIX, especially §9, 11, and 13; XXI§3, and XXXIII§46. Translation reviewed in Aphrahat, Unterweisungen, 1. und 2. Teilband, aus dem Syrischen übersetzt und eingeleitet von Peter Bruns (Freiburg, 1991) and Syriac text in F. Graffin, Patrologia Syriaca, Pars Primus (Paris, 1894).

Quoted from McCarthy's translation of the Armenian version, Saint Ephrem's Commentary on Tatian's Diatessaron, pp.276-277. Daniel's 'prophecy' of Jerusalem's eternal destruction also forms an important part of Ephrem's arguments against Julian the Apostate and the Jews' attempts to rebuild the sanctuary under his protection in his hymn Contra Julianum 4 (cf. strophes 20 and 23 in particular) (CSCO Vol. 174, Tomus 78, ed. by E. Beck 1957, pp.89 and 90).

Louis Leloir translates the Armenian text here 'la profanation de son sanctuaire, que suivront le calme et l'oubli attachés aux ruines'. Cf. Éphrem de Nisibe, Commentaire de l'Évangile Concordant ou Diatessaron, 1966, p.322. 